\title{
An Analysis on Violence and Suicide among Police Officers
}

\author{
Purda-Nicoară (Netotea-Suciu) Valeria-Liliana-Amelia ${ }^{1}$ \\ ${ }^{1}$ Academy of Economic Studies of Bucharest, Tulcea, Romania \\ Correspondence: Netotea Liliana, Loc. Tulcea, Str. Cicoarei nr. 3, Bl. 3, Sc. B, Ap. 9, Jud. Tulcea, Romania. Tel: \\ 4-024-052-5693. E-mail: amelia_netotea@yahoo.com
}

Received: November 30, $2012 \quad$ Accepted: December 17, $2012 \quad$ Online Published: April 24, 2013
$\begin{aligned} & \text { doi:10.5539/par.v2n1p84 } \\ & \text { URL: http://dx.doi.org/10.5539/par.v2n1p84 }\end{aligned}$

\begin{abstract}
Increased consumption and intensive computerization have generated an increasing interest in the production process and increased productivity at the expense of the human factor and its performance, and the progressive brutalization of occupations and organizations has become one of the most important sources of suffering at the workplace. Worrying mutations suffered by society are also reflected, of course, in individuals working for the police. For these reasons, it is necessary that being a policeman should be further examined in all its dimensions. The objective of this paper is to present some difficulties met by police officers, their behavior and their feelings, the sources of stress, pain or discomfort in the workplace so that these issues can be taken into account to improve the work climate, the professional practices in the field, and to prevent the negative impact these may have on police organizations.
\end{abstract}

Keywords: police officers, violence, suicide, improve the work climate

\section{Introduction}

The professional activity is an important issue for each individual, a center of their existence because, on the one hand, it occupies most of their time, and on the other hand, it contributes to the conception of each and every one of their selves.

By their profession, the policemen come into contact with violence, suffering or hatred, of more or less gravity, difficult to understand, and especially to face, and sometimes police officers can be the target of attacks themselves. Such acts committed against the police "enjoy" a special treatment on the part of the media such as the "news in brief" section, in written or audiovisual media, which usually focuses on the police drama, failing to show the effect of the tragic events on the institution and society. In the best case, these reprehensible acts generate promises of "zero tolerance" on the part of some members of the government, but things rarely change, and the phenomenon worsens even further.

The police profession is very special, by the authority conferred to the one who practices it, as representing the state and the citizen with the ability to compel the enforcement of the law. These attributes of the police officer, as the instrument of democracy and politics, as well as the work climate, underlie the state of dissatisfaction and insecurity felt ever more acutely by the police officers, and whose consequences are reflected on the identity of the police force.

\section{The Work Climate}

According to experts, the effects of an inadequate work environment are not insignificant, and they could become manifest in various forms, such as stress, violence, disengagement or disinterest, complaints, turnover of the best employees, absenteeism, illness and even suicide. An inadequate work climate often begins with stressed employees as a result of unresolved targets, too ambitious or unrealistic deadlines, never-ending conflicts, etc. The spark of the conflict can occur at any time, consisting in a commonplace gesture (a disturbing look, an act of impoliteness or a sudden change) and, most often, this generates a chain reaction (triggering back into attention old unresolved conflicts, verbal abuse, psychological violence, and so on). Faced with such a situation, the management is impassible or weak, and the conflict does not die out, because an unresolved problem of the work environment can only worsen in time.

Improving the work environment requires the establishment of a modern, humanistic and consistent personnel policy, which considers not only material problems, but also the improvement of human relations and training. In 
other words, the work climate is built at the highest levels of management and it is imposed "from above" through judicious application of appropriate principles, systematic actions and defining the responsibility of each member of the organization.

Violence while performing their duties and suicide have the most serious consequences on police organizations and their representatives.

\section{Violence}

Violence faced by police officers on duty is difficult to treat, and the available information on the topic is insufficient. Most data in this regard can be found in the press or on the internet, which is why the data does not always come from reliable sources of information.

In every state in the U.S., policemen killed in the performance of their duties are honored both traditionally, by erecting monuments in public places, and through the Internet, by submitting a memorial to dedicated web sites. Moreover, in some publications (L'Uniform Crime Report) publish the annual FBI report that shows all cases of police officers killed while performing their duty, in order to continue to adapt to the new weaponry or the new modes of action used by criminals and murderers, or to improve the equipment of guards (http://www.victimesdudevoir.com/pr\%C3\%A9sentation/, accessed on August 9, 2012).

In France, there is not too much talk about representatives of the law fallen while in service; a few lines in the printed press at the employee's death, some words at a parade of personalities, a little praise by some representatives of the Government, and there are only a few sites which pay tribute (http://www.victimesdudevoir.com/pr\%C3\%A9sentation/, accessed on September 8, 2012).

From the data presented on the first website created in memory of French police officers deceased during service (www.victimesdudevoir.com, accessed on September 8, 2012), one can see that, in France, in the twenty-first century (until September 9, 2012), a total of 79 policemen and 74 gendarmes, fell, as follows (see Table no. 1)

Table 1. Number of police officers deceased during service in the USA, during the period 2000 - September 8 , 2012

\begin{tabular}{ccc}
\hline Year & $\begin{array}{c}\text { Number of police officers } \\
\text { deceased during service } \\
\text { Police* }\end{array}$ & $\begin{array}{c}\text { Number of police officers } \\
\text { deceased during service } \\
\text { Constabulary** }\end{array}$ \\
\hline 2000 & 6 & 7 \\
2001 & 11 & 1 \\
2002 & 7 & 6 \\
2003 & 9 & 7 \\
2004 & 9 & 3 \\
2005 & 2 & 5 \\
2006 & 2 & 13 \\
2007 & 6 & 6 \\
2008 & 5 & 8 \\
2009 & 7 & 5 \\
2010 & 7 & 13 \\
2011 & 4 & 0 \\
2012 & 4 & 0 \\
Total & 79 & 74 \\
\hline
\end{tabular}

Note: * data available at: http://www.victimesdudevoir.com/saint-martin/les-victimes-au-21e-s/, accessed on September 8, 2012

** data available at: http://www.victimesdudevoir.com/saint-martin/les-victimes-au-21e-s/, accessed on September 8, 2012

As for the number of police officers deceased during service in the USA, according to the data provided by the official web site of Officer Down Memorial Page, the situation is as follows (Table no. 2) (http://www.odmp.org/search/year/, accessed on September 8, 2012): 
Table 2. Number of police officers deceased during service in the USA, during the period 2000 - September 8 , 2012

\begin{tabular}{cccccc}
\hline Year & $\begin{array}{c}\text { Number of police } \\
\text { officers deceased } \\
\text { during service } \\
\text { Total, of which: }\end{array}$ & Male & Female & $\begin{array}{c}\text { Average age } \\
\text { (years) }\end{array}$ & $\begin{array}{c}\text { Average time spent in } \\
\text { service }\end{array}$ \\
\hline 2000 & 164 & 157 & 7 & 39 & 11 years 1 month \\
2001 & 242 & 230 & 12 & 38 & 11 years 4 months \\
2002 & 159 & 144 & 15 & 39 & 11 years \\
2003 & 149 & 143 & 6 & 38 & 10 years 4 months \\
2004 & 166 & 157 & 9 & 40 & 12 years 10 months \\
2005 & 165 & 160 & 5 & 39 & 11 years 1 month \\
2006 & 161 & 152 & 9 & 38 & 11 years 5 months \\
2007 & 201 & 192 & 9 & 40 & 11 years 4 \\
2008 & 152 & 140 & 12 & 40 & 11 years 11 \\
2009 & 139 & 136 & 3 & 40 & 11 years 12 months \\
2010 & 171 & 163 & 8 & 42 & 11 years 11 months \\
2011 & 173 & 162 & 11 & 41 & 13 years 3 months \\
2012 & $79 *$ & 70 & 9 & 41 & 13 years \\
Total & 2121 & 2006 & 115 & 39.62 & 11 years 7 months \\
\hline
\end{tabular}

Note: *on the $08^{\text {th }}$ of September 2012

The situation of police officers deceased during performing their duties in Canada (as shown in the information available at http://www.victimesdudevoir.com/a-1-\%C3\%A9tranger/s, accessed on September 9, 2012), is as follows (Table 3).

Table 3. Number of police officers deceased during service in Canada, during the period $2001-2008$

\begin{tabular}{cc}
\hline Year & $\begin{array}{c}\text { Number of police officers } \\
\text { deceased during service }\end{array}$ \\
\hline 2001 & 7 \\
2002 & 12 \\
2003 & 6 \\
2004 & 7 \\
2005 & 11 \\
2006 & 6 \\
2007 & 4 \\
2008 & 2 \\
Total & 55 \\
\hline
\end{tabular}

In Romania, the fallen officers is a delicate topic, and one can usually find information on this topic especially on forums of representatives of the profession (http://www.politisti.ro/topic/244-eroii-politiei-romane/, accessed on September 9, 2012) and, to the best of my knowledge, there are no sites commemorating the heroes of police. My personal hope is that this happens because there are no such situations, and not because the subject is taboo.

\section{Suicide}

Suicide is a scourge that the contemporary society faces, a major health problem which worsens continuously (in recent years, suicide rates have increased in some countries by as much as $60 \%$ ), and it has come to be one of the most important causes of mortality worldwide. Proof of this is the existence of multiple global associations and foundations established to prevent suicide and promote mental health, which are holding regular events with the same theme, including the "World Day for the Prevention of Suicide", organized by the World Health Organization (WHO) in collaboration with the International Association for Suicide Prevention (IASP). In the 
report published on the occasion of the tenth edition of the event in 2012, it was indicated that in the world, a person commits suicide every 40 seconds, and about $5 \%$ of the world population has tried at least once to commit suicide (http://iasp.info/wspd/pdf/2012_wspd_brochure.pdf, accessed on September 8, 2012).

On police suicides, there are different opinions (Table no. 4). Thus, most of the publications on the subject claim that suicidal acts occur in the police also, but with a higher frequency than for those employed in other fields. For example, in an article published by "Le Poste" on the $23^{\text {rd }}$ of January 2012 , it is said that the police suicide rate in 2009 (35 per 100,000 persons) was two times higher than the suicide rate of employees in other industries (16 per 100,000 employees, which is the suicide rate recorded by France Telecom telephone organization, ranked second), referring to data from the National Union of Police Officers. However, there were few responses, including a report from a police union and several articles in the media, "Le Poste" the $23^{\text {rd }}$ of January 2012 (http://archives-lepost.huffingtonpost.fr/article/2009/12/01/1819411_le-suicide-des-policiers-parlons-en.html,

accessed on September 8, 2012) and "Le Figaro" in the $21^{\text {rd }}$ November 2009 (http://www.victimesdudevoir.com/les-suicides/presse-suicides/, accessed on September 8, 2012).

Table 4. Number of police officers who committed suicide in France, during the period 2005-2009

\begin{tabular}{cc}
\hline Year & Number of suicide cases \\
\hline 2005 & 6 \\
2006 & 11 \\
2007 & 7 \\
2008 & 9 \\
2009 & $9^{*}$ \\
Total & 2 \\
\hline
\end{tabular}

Note: data available at: http://www.victimesdudevoir.com/saint-martin/les-victimes-au-21e-s/, accessed on 08.09.2012

*on the $01^{\text {st }}$ of November 2009

According to other sources (http://iasp.info/wspd/pdf/2012_wspd_brochure.pdf, accessed September 8, 2012) among the facilitating factors contributing to death by suicide among the police officers, one can include the following: the presence of stressful life situations (family or interpersonal conflicts, separations, the presence of legal or disciplinary problems, the existence of financial difficulties, difficulties related to work, etc.). Also, in the case of subjects with low defense systems, periods of mourning, serious physical diseases (HIV, cancer) or other medical conditions, periods of economic crisis and unemployment, which increase social vulnerability, and traumas experienced in childhood or presence of prolonged stress, specific professions, such as doctors, military personnel and police officers or imprisoned, all these can contribute towards such decisions.

Comparing suicide rates recorded in the period 1990-1998, in some U.S. police departments (the police departments in New York, Chicago, Los Angeles, San Diego, Phoenix, Dallas, Houston, San Antonio), and the FBI, with those calculated for the general population, some authors ("Police Officer Suicide: Frequency and officer profiles" by Michael G. Aamodt \& Nicole A. Stalnaker at the Radford University, June 20, 2006, http://www.policeone.com/health-fitness/articles/137133/, accessed on September 9, 2012) have established that the assumption that the suicide rate is abnormally high for police officers not is supported by the data. Thus, it was found that the suicide rate for police officers, which is 18.1 per 100000 people is higher by $52 \%$ than the one calculated for the general population, 11.4 per 100000 population, but $26 \%$ lower than that calculated for the appropriate comparator group (white males, aged 25-55 years). The differences between the two compared suicide rates are explained by the fact that most police officers are male (89\%), white (81\%), aged 21 to 55, (according to U.S. Crime Reports 1997). In other words, although the suicide rate among police officers is higher than the same index of the general population, it is a lower suicide rate than the one determined for the sample of the general population with similar characteristics (age, race, sex).

\section{Discussion}

In Romania, there is very little data available on the subject (some discussions on forums, several articles in the press) and therefore one can not perform a pertinent analysis of suicide with the police profession.

With globalization, even if the small amount of existing data on officers deceased during service or by suicide would be consistent with reality; it is time for our country to take care of its police forces, as the threats will soon occur. 


\section{References}

10th World Suicide Prevention Day. (2012). Suicide Prevention across the Globe: Strengthening Protective Factors and Instilling Hope. Retrieved from http://iasp.info/wspd/pdf/2012_wspd_brochure.pdf

Aamodt, M. G., \& Stalnaker, N. A. (2006, June 20). Police Officer Suicide: Frequency and officer profiles. Retrieved from http://www.policeone.com/health-fitness/articles/137133

ODMP. (n. d.). Honoring Officers Killed in 2012. Retrieved from http://www.odmp.org/search/year

Le suicide des policiers, parlons-en? (n. d.). Retrieved from http://archives-lepost.huffingtonpost.fr/article/2009/12/01/1819411_le-suicide-des-policiers-parlons-en.html

Les policiers victimes du devoir. (n. d.). Retrieved from http://www.victimesdudevoir.com/pr\%C3\%A9sentation

Les victimes du devoir à l'étranger. (n. d.).Retrieved from http://www.victimesdudevoir.com/a-1-\%C3\%A9tranger

Police : un syndicat s'alarme des suicides. (n. d.). Retrieved from http://www.victimesdudevoir.com/les-suicides/presse-suicides

Police: un syndicat s'alarme des suicides. (n. d.). Retrieved from http://www.lefigaro.fr/flash-actu/2009/11/02/01011-20091102FILWWW00394-police-un-syndicat-s-alarm e-des-suicides.php

Romanian Police Heroes - General Discussion - Forum. (n. d.). Retrieved from http://www.politisti.ro/topic/244-eroii-politiei-romane 